\title{
Species richness and composition of macroalgal assemblages of a disturbed coral reef in the Gulf of California, Mexico
}

\section{Riqueza de especies y composición de los ensambles de macroalgas de un arrecife de coral impactado en el Golfo de California, México}

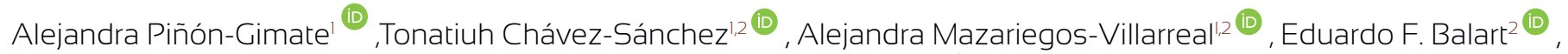 \\ Elisa Serviere-Zaragoza2,3 (1)
}

\begin{abstract}
:
Background and Aims: In September 2001, the coral reef of the San Lorenzo Channel, La Paz Bay, Gulf of California, Mexico, was affected by the stranding of the oil tank vessel "Lázaro Cárdenas II". Soon afterwards, hurricane "Juliette" hit the area with strong winds and water movement, disturbing the reef again. After that, three zones could be observed in the reef: one directly impacted by the shipwreck, one indirectly impacted by the hurricane, which moved and accumulated the coral debris left by the shipwreck, and the third one, which was not impacted. Later, a monitoring program was established to determine the degree of recovery of macroalgal assemblages in both impacted zones compared with the non-impacted one. Methods: From February 2005 to December 2007, macroalgae were collected seasonally by scuba divers in the three zones. In each zone, three to five thalli of all conspicuous algae, five rocks and five fragments of dead coral covered with macroalgal turfs were collected. Species number and composition of macroalgae assemblages were compared between zones and between years.

Key results: A total of 117 species were found, 70 belonged to the phylum Rhodophyta, 25 to Ochrophyta-Phaeophyceae, and 22 to Chlorophyta. Macroalgal species richness and composition of the impacted zones were not different from the control zone, even between years.

Conclusions: Macroalgal assemblages in the San Lorenzo Channel coral reef were able to recover, regardless of the modification of the substrate caused by the stranding and the hurricane "Juliette" in 2001. Therefore, it is important to implement monitoring efforts in case of anthropogenic or natural disturbance to document the extension of damage, recovery of the communities, and propose mitigation strategies if necessary.
\end{abstract}

Key words: hurricane, recovery, shipwreck, species richness, turf algae.

\section{Resumen:}

Antecedentes y Objetivos: El arrecife de coral del Canal de San Lorenzo, Bahía de La Paz, Golfo de California, México, se vio afectado por el varamiento del tanque petrolero "Lázaro Cárdenas II" en septiembre de 2001. Poco después, el huracán "Juliette" golpeó el área con fuertes vientos y movimiento de agua que perturbaron nuevamente al arrecife. Después de esto, se pudieron observar tres zonas en el arrecife: una directamente impactada por el encallamiento, otra indirectamente impactada por el huracán, que movió y acumuló los restos de coral que dejó el encallamiento, y la tercera no impactada. Posteriormente, se estableció un programa de monitoreo para determinar el grado de recuperación de los ensambles de macroalgas en ambas zonas impactadas en comparación con la zona no impactada.

Métodos: De febrero de 2005 a diciembre de 2007, se recolectaron estacionalmente macroalgas en las tres zonas por medio de buceo. En cada zona, de tres a cinco talos de las especies de macroalgas conspicuas, cinco rocas y cinco fragmentos de coral muerto cubiertos con tapetes macroalgales fueron recolectados. El número de especies y la composición de los ensambles de macroalgas fueron comparados entre zonas y entre años.

Resultados clave: Se encontró un total de 117 especies, 70 pertenecientes al filo Rhodophyta, 25 a Ochrophyta-Phaeophyceae y 22 a Chlorophyta. La riqueza de especies y composición de las macroalgas en las zonas impactadas no fueron diferentes de la zona control ni entre años.

Conclusiones: Los ensambles de macroalgas en el arrecife de coral del Canal de San Lorenzo pudieron recuperarse independientemente de la modificación del sustrato a causa del varamiento del buque y del huracán “Juliette" en 2001. Por lo anterior, es importante implementar esfuerzos de monitoreo para que, en caso de que ocurra una perturbación antropogénica o natural, se pueda documentar la extensión del daño, la recuperación de la comunidad y proponer estrategias de mitigación si es necesario.

Palabras clave: céspedes algales, encallamiento, huracán, recuperación, riqueza de especies.

${ }^{1}$ Instituto Politécnico Nacional, Centro Interdisciplinario de Ciencias Marinas, Av. Instituto Politécnico Nacional s/n, 23096 La Paz, Baja California Sur, Mexico.

${ }^{2}$ Centro de Investigaciones Biológicas del Noroeste (CIBNOR), calle IPN 195, 23096 La Paz, Baja California Sur, Mexico.

${ }^{3}$ Author for correspondence: serviere04@cibnor.mx
Received: December 13, 2019. Reviewed: February 13, 2020.

Accepted by Marie-Stéphanie Samain: April 15, 2020. Published Online first: May 11, 2020.

Published: Acta Botanica Mexicana 127(2020).

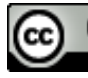

To cite as: Piñón-Gimate, A., T. Chávez-Sánchez, A. Mazariegos-Villarreal, E. F. Balart and E. Serviere-Zaragoza. 2020. Species richness and composition of macroalgal assemblages of a disturbed coral reef in the Gulf of California, Mexico. Acta Botanica Mexicana 127: e1653. DOI: 10.21829/abm127.2020.1653

e-ISSN: $2448-7589$ 


\section{Introduction}

Macroalgae can be considered as undesirable companions of coral reefs because they can outcompete corals, playing a significant role in coral reef degradation (Hughes, 1994). However, macroalgae do not directly kill healthy corals, but grow on dead or ill individuals (Diaz-Pulido and McCook, 2002, 2004), although some species can prevent coral settlement and growth (McCook et al., 2001). Nowadays, between 10 to $40 \%$ of the surface area of the coral reefs around the world are covered with macroalgae, making them an essential component of these communities (Bruno et al., 2014). They contribute to reef construction (Littler and Littler, 1984) and are key components of coral reef food webs (Bellwood et al., 2018).

Macroalgae are exposed to different pressures (either physical or chemical, natural or anthropogenic) that could modify their composition, distribution and abundance within the coral reef community, by changes in their habitat (Diaz-Pulido et al., 2007). Within natural pressures, there are disturbances such as cyclones that occur along and across the entire reef, particularly during the summer-autumn months; they are considered one of the most important disturbances for coral communities and they are also critical to the algal community (Diaz-Pulido et al., 2007; Beeden et al., 2015). Moreover, the increase of human activities in coastal waters, such as marine traffic, could also affect macroalgal communities through habitat destruction or sediment burial, resulting in smothering that will prevent algae to fixate to the substrate and/or cause anoxic conditions where algae cannot survive (Marshal and Edgar, 2003; Lirman et al., 2010). On the other hand, anthropogenic nutrient enrichment can cause an increase in macroalgae communities of coral reefs, and ephemeral species with rapid growth can outgrow and compete with the coral community causing a change from coral reef to macroalgae dominated reef (Lapointe et al., 2004). The extent of changes produced by natural and anthropogenic disturbances largely depends on the previous history and frequency of disturbances, geographical location, and structure of the coral reef (Gardner et al., 2005; Lirman et al., 2010; Beeden et al., 2015).

Any disturbance that causes damage to corals, such as bleaching and coral death, could result in significant in- creases in the available area for algal turfs and other opportunistic algae, that can be distinct to the naturally occurring algal communities in taxonomic composition and relative abundance of the different taxa (Hatcher, 1984; Diaz-Pulido et al., 2007; Schroeder et al., 2008). In some cases, the intensity of the herbivory can suppress dense macroalgal growths (Edmunds et al., 2019), and recovery of macroalgal turfs to their pre-disturbed state will occur within one year, while large seaweeds such as Sargassum C. Agardh may require longer (three-four years) if conditions remain unchanged (Diaz-Pulido et al., 2007). Nevertheless, macroalgal communities with different taxonomic composition can be permanently established because the conditions set are now favorable to overgrow previous assemblages (Hatcher, 1984).

In the Gulf of California, two events in the marine protected area, "Archipiélago of the Espíritu Santo Island" in La Paz Bay, Baja California Sur, took place in 2001, leaving considerable damage in the coral reef community. The San Lorenzo Channel coral reef was severely affected by the temporal stranding of the vessel "Lázaro Cárdenas II" in September. Later, in the same month, hurricane "Juliette" brought strong winds and currents that caused more damage to the coral reef. The removal of coral fragments and restoration of the affected areas were realized afterwards (Balart et al., 2010). From 2005 to 2007, a seasonal monitoring of macroalgae was carried out. In this study, the species richness and composition of macroalgae from the monitoring program were analyzed, comparing impacted and non-impacted zones, to evaluate whether these events affected the macroalgal assemblages in the San Lorenzo Channel coral reef.

\section{Material and Methods}

\section{Study area}

The San Lorenzo Channel coral reef is formed by an almost continuous platform of the branched coral Pocillopora spp., which, unlike more developed coral reefs, lacks distinct zones. The reef had an estimated total cover of around one hectare, a $97 \%$ cover of living coral, and is 5-10 m deep (Balart et al., 2010). It is located on the southwest coast of the Gulf of California, between the south portion of the Island Espíritu Santo and Pichilingüe, inside La Paz Bay 
$\left(24^{\circ} 23^{\prime} 12.5^{\prime \prime} \mathrm{N}, 110^{\circ} 18^{\prime} 55.5^{\prime \prime} \mathrm{W}\right)$, in a homonymous channel with strong tidal currents $\left(6.73 \mathrm{~cm} \mathrm{~s}^{-1}\right)$ and a maximum depth of 20 m (Obeso-Nieblas and Jiménez-Illescas, 1989; Fig. 1). The rainfall period in the region is from August to October, September being the rainiest month of the year (180 mm) (Obeso-Nieblas, 2003). Temperature presents seasonal patterns with the minimum during winter $\left(20^{\circ} \mathrm{C}\right)$ and maximum during summer $\left(30^{\circ} \mathrm{C}\right)$; average salinity is 36 ups (Reyes-Salinas et al., 2003).

After the disturbances occurred, three different zones could be observed in the San Lorenzo Channel coral reef, depending on the damage suffered. The first zone (zone 1) corresponded to the reef area that was directly impacted by the vessel "Lázaro Cárdenas II", on September
22,2001 , which removed all the coral cover by leaving only a sandy bottom. The total damaged area was $847 \mathrm{~m}^{2}$. In this zone, as part of a restoration program that was implemented, concrete modules ( 30 units of $1 \mathrm{~m}^{3}$ ) were placed in October 2002 and used to cement coral fragments, being the only hard substrates available. At the end of September 2001, the adjacent area (zone 2) was damaged by the huge number of coral fragments (over 50 tons) swept to it, from the previous damage zone 1 , by the force of the currents originated by the hurricane "Juliette". Dead coral fragments buried live coral and the total area damaged was of approximately $7625 \mathrm{~m}^{2}$. After both disturbances, zone 2 preserved a substantial part of its physical and biological characteristics, but with new bare spaces and rubble of dead coral.

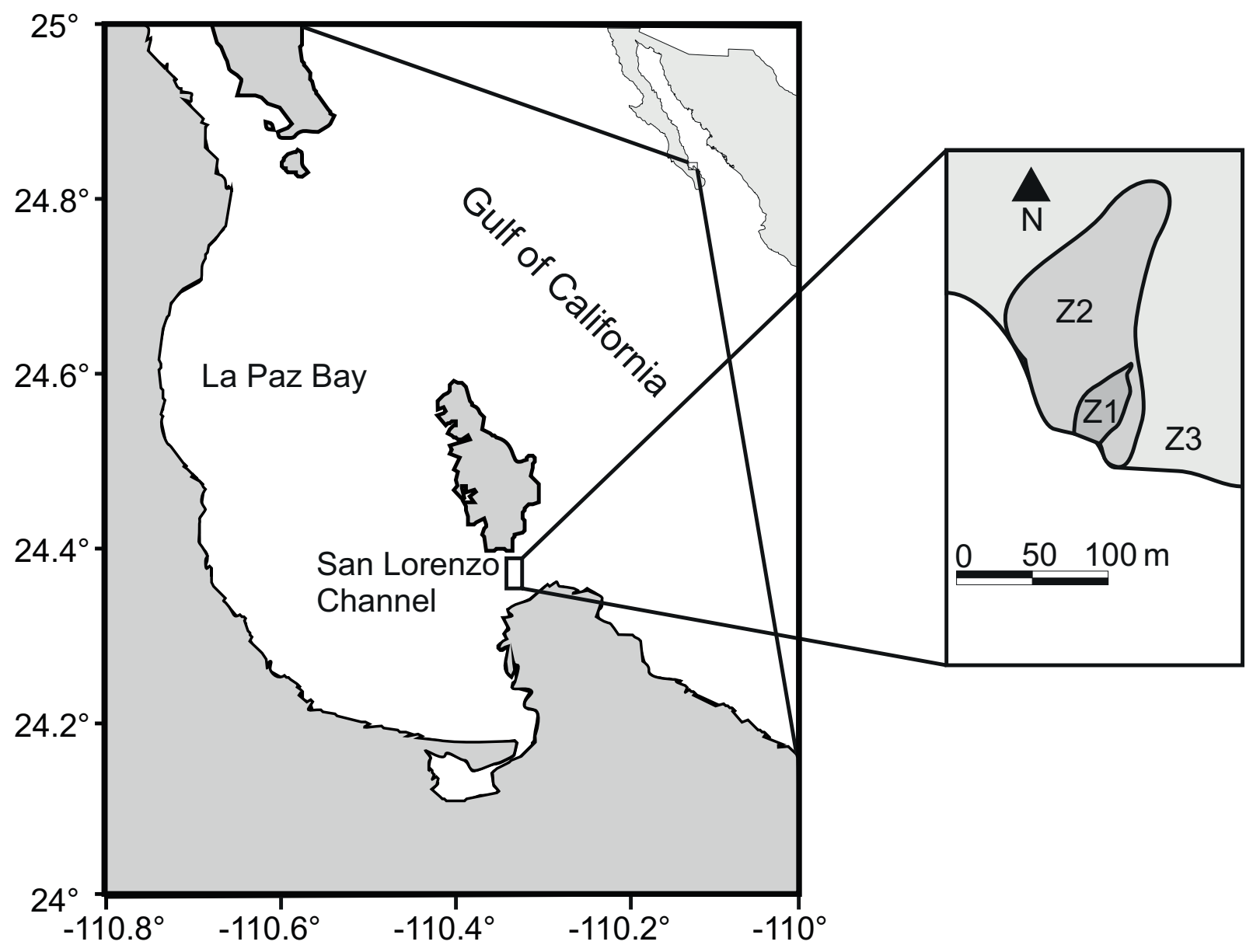

Figure 1: San Lorenzo Channel coral reef, La Paz Bay, Gulf of California, Mexico. Z1=zone 1, Z2=zone 2, Z3=zone 3. 
Zone 3 corresponded to the non-impacted reef area with live coral heads, with a total area of $1217 \mathrm{~m}^{2}$; for this reason, it was considered the control zone.

\section{Field and laboratory work}

Surveys were done every three months from February 2005 to December 2007, completing three annual periods, except in the first year when only three surveys were possible $(\mathrm{N}=11)$. In each zone, surveys were done within an area of $900 \mathrm{~m}^{2}$ that was covered by the same scuba diver for 60 minutes. The area was measured using a compass and a $100 \mathrm{~m}$ line.

In each zone, three to five thalli of all conspicuous algae were collected. Conspicuous algae (CA) were identified as larger ( $>10 \mathrm{~cm}$ height) and anatomically complex erect algal forms that were found as sparse aggregations or as individuals upon rocks and fragments of dead coral. Additionally, five rocks and five fragments of dead coral covered with macroalgal turfs were collected. Macroalgal turfs $(T)$ refer to a ubiquitous and multispecies assemblage of short algae ( $<10 \mathrm{~cm}$ height), that comprised different morphologies as filamentous (corticated and uncorticated), foliose and calcareous articulated, among others (Connell et al., 2014).

Algae were rinsed with marine water, transported to the laboratory, and then preserved in formaldehyde $4 \%$. They were identified to the lowest taxonomic level possible by means of their morphological characteristics, using the references for the region (Setchell and Gardner, 1924; Dawson, 1944; Norris, 2010, 2014). Current species names were revised in AlgaeBase (Guiry and Guiry, 2020); with this information a presence-absence matrix was elaborated, and a taxonomic list was made.

Daily records of surface ocean temperature $\left({ }^{\circ} \mathrm{C}\right)$ of the San Lorenzo Channel were obtained for 2005-2007 from the NOAA (National Oceanic Atmospheric Administration), using 0.1-degree quadrants. Seasonal averages were calculated with the data of the three months before the collection date.

\section{Analysis}

To evaluate whether the sampling effort was representative, species rareness cumulative curves were obtained with the presence-absence matrix data. The species richness estimators used were Chao 2, Jackknife 1 , and Bootstrap, which could be utilized when only presence-absence data are available. The calculations were done in the package PRIMER version 6.0 (Clarke and Warwick, 2001).

Changes in species richness between zones and years were assessed using a two-way ANOVA test (Zar, 2009). Differences in the proportion of species growing as conspicuous algae or in macroalgal turfs between zones and years were probed through a chi-square test (Zar, 2009). Distributional patterns of species for each zone and season were analyzed using multivariate techniques applied to the presence-absence data. A Sørensen similarity matrix was obtained; no previous transformations were required. An ordination analysis by means of a non-metric multidimensional scaling (MDS) to the matrix data was carried out. Finally, a two-way analysis of similarities (ANOSIM) was performed to determine the presence of differences in general algal structure, analyzing zones and years. As a complement, a similarity percentage test (SIMPER) was used to determine which species contributed to defining the groups depicted in the ordination; these tests were run with the software PRIMER ver. 6.0 (Clarke and Warwick, 2001).

\section{Results}

Accumulation curves of species showed that the estimated number of macroalgae species in the San Lorenzo Channel coral reef were 132 for Bootstrap, 151 for Jackknife 1, and 164 for Chao 2 (not shown). A total of 117 species were found during the sampling period, which means that the observed number of species represented between 71 and $89 \%$ of the potential maximum species richness.

From the 117 species, 32 were identified as conspicuous algae and 85 were part of the turfs growing on rocks or on coral fragments. Of the total number, 70 species belonged to the phylum Rhodophyta (60\%) with 37 genera, 20 families, 10 orders and one class; 25 species corresponded to Ochrophyta-Phaeophyceae (21\%) with 13 genera, 7 families, 4 orders and one class, and 22 species to Chlorophyta (19\%) with 10 genera, 10 families, 5 orders and one class. The most abundant families were Rhodomelaceae with 20 species and Ceramiaceae with 13 (Appendix). From the total number of species, five had been previously reported 
as endemic to the region: Codium amplivesiculatum Setchell \& N.L. Gardner, Sargassum horridum Setchell \& N.L. Gardner, Sphacelaria brevicornis Setchell \& N.L. Gardner, Gracilaria marcialana E.Y. Dawson and Palisada pedrochei J.N. Norris.

In general terms, zone 2 had the highest number of species (87), with 50 genera, 33 families, 18 orders and three classes, followed by zone 1 (77), with 43 genera, 28 families, 14 orders and three classes; and zone 3 (76), with
44 genera, 28 families, 15 orders and three classes (Fig. 2). The year with the highest number of species was 2007 (95), followed by 2006 (77) and 2005 (61) (Fig. 2). Accordingly, significant differences between 2007 and 2005 were found $\left(F_{2,24}=3.6 ; p<0.04\right)$, but not between zones $\left(F_{2,24}=0.3 ; p=0.7\right)$ or in the years in relation to the zone $\left(F_{4,2}=1.3 ; p>0.2\right)$. In 2007 a change in seasonal patterns was observed, especially in zone 2, where the richness increased during the warmer months, unlike previous years (Fig. 3). The conspicuous

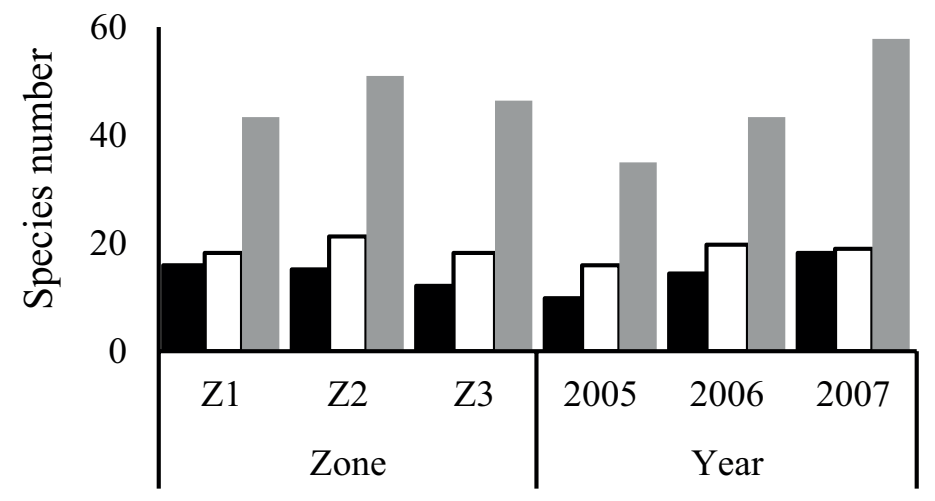

-Chlorophyta QOchrophyta: Phaeophyceae $\square$ Rhodophyta

Figure 2: Macroalgae species number by phylum in the San Lorenzo Channel coral reef, La Paz Bay, Gulf of California, Mexico.

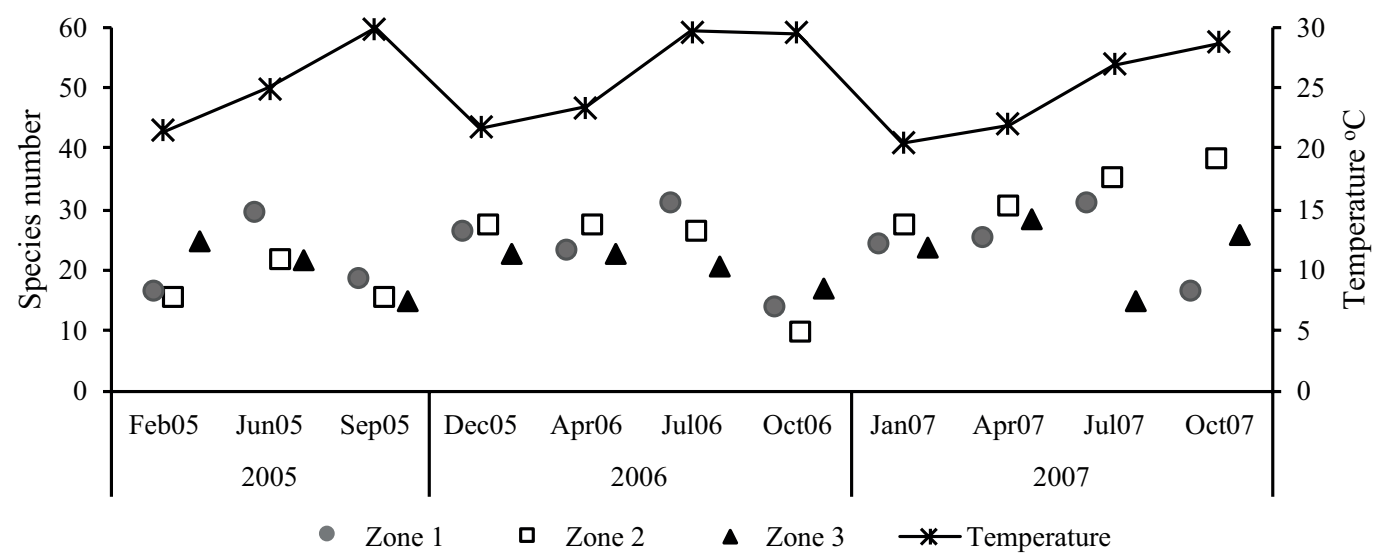

Figure 3: Macroalgae species number by zone and year in the San Lorenzo Channel coral reef, La Paz Bay, Gulf of California, Mexico. 
algae proportion oscillated between $26 \%$ and $31 \%$ of the total richness by zone or year (Fig. 4). No significant differences were found in the proportions of conspicuous algae or macroalgae growing on turfs between zones $\left(\chi^{2}=2.3 ; p\right.$ $=0.7)$ or years $\left(\chi^{2}=0.2 ; p=0.9\right)$.

The MDS showed no aggregation pattern by zone or year (Stress: 0.26; Fig. 5). Moreover, no significant dif- ferences were detected in the composition of species between zones ( $R=0.05, p=0.8)$, and years $(R=0.06, p=0.2)$. SIMPER analysis estimates that the average similarity inside zones or years was low, from $36 \%$ to $39 \%$, and dissimilarity was high, between $60 \%$ and $63 \%$. Since no aggregations between the species composition of each zone or year were found, no more SIMPER results are shown.

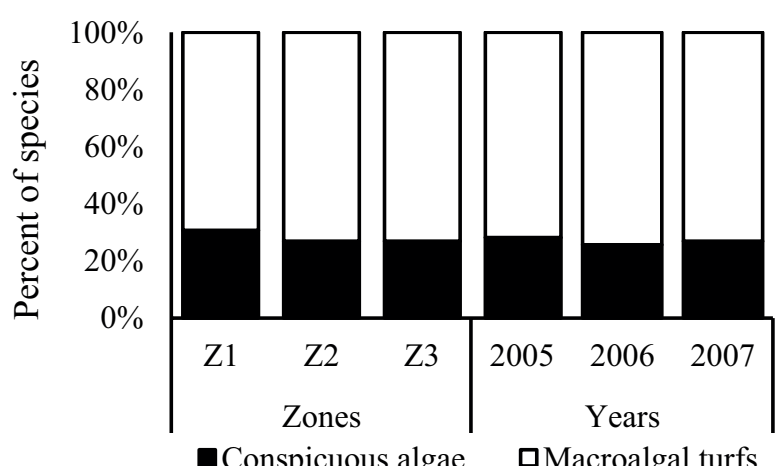

Figure 4: Percentage of conspicuous algae (black) and macroalgae forming turfs (white) in the San Lorenzo Channel coral reef, La Paz Bay, Gulf of California, Mexico.

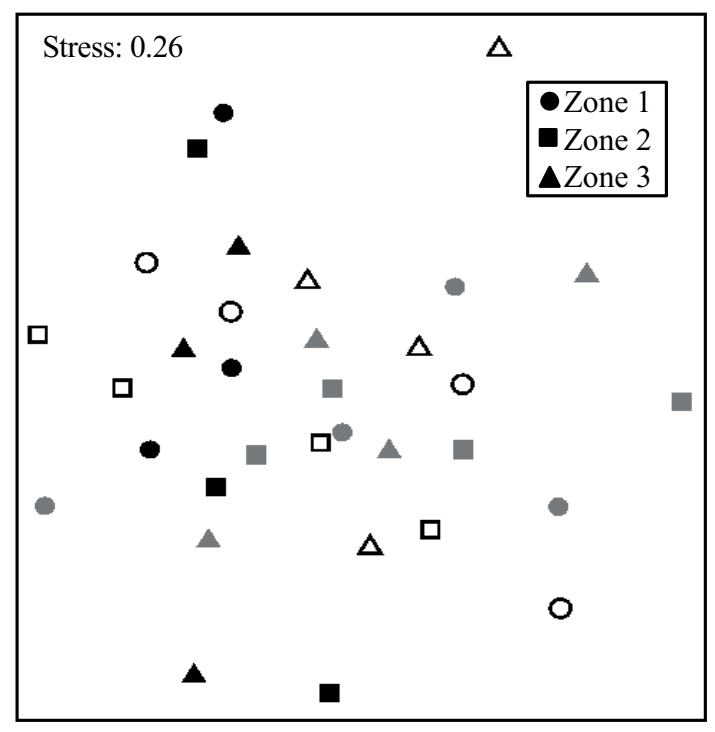

Figure 5: Multidimensional scaling (MDS) of macroalgal assemblages in the San Lorenzo Channel coral reef, La Paz Bay, Gulf of California, Mexico. 2005=black symbols; $2006=$ grey symbols; $2007=$ white symbols. 


\section{Discussion}

A total of 117 marine benthic algal species were found in the coral reef of the San Lorenzo Channel, with $85 \%$ of the potential species richness of the reef according to the bootstrap method for species richness estimation (Petersen and Meier, 2003), suggesting that this is an area of high species richness, as previously discussed by Riosmena-Rodríguez and Paul-Chávez (1997) and Casas-Valdez et al. (2000). The number of species reported in this study represented $43 \%$ of the total registered species of the La Paz Bay, which is similar to that reported for nearby sites as Espíritu Santo Island (106 spp., Paul-Chávez and Riosmena-Rodríguez, 2000) and Punta Galeras (117 spp., Rodríguez-Morales and Siqueiros-Beltrones, 1999).

From the 117 species, the highest percentage belonged to red algae, followed by brown and green algae. In a previous study for the same channel, the highest percentage of the algae corresponded to the red algae (70\%), while only $10 \%$ corresponded to green algae (Iglesias-Prieto et al., 2003). Other authors found the same tendency in adjacent places such as Balandra, Punta Galeras and Espíritu Santo Island (Rocha-Ramírez and Siqueiros-Beltrones, 1991; Rodríguez-Morales and Siqueiros-Beltrones, 1999; Riosmena-Rodríguez and Paul Chávez, 1997; Casas-Valdez et al., 2000). Several authors have discussed that this pattern might be linked with the high diversity of red algae, as well as the great variety of life forms and more efficient reproductive strategies, for example, the formation of spores that allows them to resist and manifest in all seasons of the year (Mathieson, 1989; Woelkerling, 1990; Mateo Cid et al., 1993).

The relative dominance of turf forming algae in the San Lorenzo Channel has also been observed in other reef systems that have been impacted by hurricanes or storms, such as in a tropical reef community in the Mexican Caribbean (van Tussenbroek and Collado-Vides, 2000), as well in the Gulf of California (Scrosati, 2001). In the case of the Gulf of California, turfs are well-represented in number of species, which could be associated with the high seasonal variation in the temperature (i.e., Littler and Littler, 1981), irradiance and nutrient availability (Pacheco-Ruíz and Zertuche-González, 1999), and hurricanes (Tello-Velasco, 1986), among other factors. This growth form allows them to persist in areas with high environmental availability (Hay,
1981), such as the San Lorenzo Channel, a zone with high energy (high-velocity currents), which may favor the presence of macroalgal turfs. In other coral reefs impacted by a shipwreck, changes in macroalgal assemblages have been attributed to the establishment of unpalatable assemblages of macroalgae that were avoided by grazers (Hatcher, 1984), or to the addition of nutrients by the remains of the wreckage and the decrease in abundance by some herbivores (Marshal and Edgar, 2003).

Despite the fact that a differential damage was caused to the reef by the stranding of the vessel and later by the hurricane, no significant differences were found in species richness and composition between the impacted and non-impacted zones or between years, as was expected. Macroalgal assemblages between zones were similar from the beginning of the monitoring program, possibly because the recovery of macroalgal assemblages occurs within the first years after the disturbance took place (Diaz-Pulido et al., 2007). In our case, sampling began three years after the disturbances. Additionally, despite the changes in substrate caused by the vessel "Lázaro Cárdenas II" and the hurricane, the three zones had suitable substrate for macroalgae attachment. It is important to note that we did not evaluate the abundance of macroalgae in the three zones, as it is possible that there could be differences in macroalgal abundances among them as found in other studies (Rogers, 1996, 1997).

The only appreciable change was observed in 2007, when richness was higher during the warmest months, especially in zone 2, contrasting what was observed in other years and other localities of the Gulf of California, in which the richness was low. In this regard, water temperature is a critical factor that limits growth rate and species distribution (e.g., Lüning, 1993; Hurd et al., 2014) and could be, in part, responsible for the deviation observed in 2007. During this year, lower temperatures than those reported for previous years were observed $\left(-2{ }^{\circ} \mathrm{C}\right)$ (Fig. 3) in the La Paz Bay, a situation which was related to the influence of the cold phase of the El Niño-Southern Oscillation (ENSO), being 2007 the coldest year in the first decade of the 21st century (Guevara-Guillén et al., 2015).

Macroalgal assemblages in the San Lorenzo Channel coral reef were able to recover, regardless of the modifica- 
tion of the substrate caused by the stranding and the hurricane "Juliette" in 2001. Therefore, it is important to implement monitoring efforts in case of anthropogenic or natural disturbance occurs to document the extension of damage, recovery of the communities, and propose mitigation strategies if necessary.

\section{Author contributions}

EFB and ESZ conceived and designed the study. EFB, TCS and AMV carried out field and laboratory work. TCS and APG analyzed and interpreted the results. APG wrote the manuscript with the aid of TCS, AMV and ESZ. All authors read and approved the final manuscript.

\section{Funding}

Research funds were granted to EFB through the Comision Nacional para el Conocimiento y Uso de la Biodiversidad (CONABIO), project CT001.

\section{Acknowledgments}

We are grateful to Juan José Ramírez Rosas, Horacio Bervera León and Mario Cota Castro for field help collecting samples. We also like to thank Alma Rosa Rivera Camacho for help with sample identification.

\section{Literature cited}

Balart, E. F., H. Reyes Bonilla, J. A. De León González, E. ServiereZaragoza, L. G. Hernández Moreno, R. Cabral Tena, A. Mazariegos Villarreal and A. Ortega Rubio. 2010. Informe final del Proyecto CT001 "Programa de monitoreo de la restauración de arrecife coralino afectado por el Buque Tanque Lázaro Cárdenas II, y de las comunidades arrecifales de la región del Parque de Loreto, Baja California Sur, financiado por la Comisión Nacional para el Conocimiento y Uso de la Biodiversidad. Centro de Investigaciones Biológicas del Noroeste, S.C., La Paz, México. 80 pp.

Beeden, R., J. Maynard, M. Puotinen, P. Marshall, J. Dryden, J. Goldberg and G. Williams. 2015. Impacts and recovery from severe tropical cyclone Yasi on the Great Barrier Reef. PLoS ONE 10(4): e0121272. DOI: https://doi.org/10.1371/ journal.pone.0121272

Bellwood, D. R., S. B. Tebbett, O. Bellwood, M. Mihalitsis, R. A. Morais, R. P. Streit and C. J. Fulton. 2018. The role of the reef flat in coral reef trophodynamics: past, present and future. Ecology and Evolution 8(8): 4108-4119. DOI: https:// doi.org/10.1002/ece3.3967

Bruno, J. F., W. F. Precht, P. S. Vroom and R. B. Aronson. 2014 Coral reef baselines: How much macroalgae is natural? Marine Pollution Bulletin 80(1-2): 24-29. DOI: https://doi. org/10.1016/j.marpolbul.2014.01.010

Casas-Valdez, M., R. A. Núñez-López, M. B. Cruz-Ayala, I. Sánchez-Rodríguez, R. Vázquez-Borja and G. E. López. 2000. Biodiversity and biogeographic affinities of the algal flora of Baja California Sur: A synthesis of the literature. In: Munawar, M., S. G. Lawrence, I. F. Munawar and D. F. Malley (eds.). Aquatic Ecosystem of Mexico: Status and scope. Backhuys Publishers. Leiden, Netherlands. pp. 273-282.

Clarke, K. R. and R. M. Warwick. 2001. Change in marine communities: an approach to statistical analysis and interpretation. Natural Environment Research Council. Plymouth, UK. $172 \mathrm{pp}$

Connell, S. D., M. S. Foster and L. Airoldi. 2014. What are algal turfs? Towards a better description of turfs. Marine Ecology Progress Series 495: 299-307. DOI: https://doi.org/10.3354/meps10513

Dawson, E. Y. 1944. The marine algae of the Gulf of California. Allan Hancock Pacific Expeditions 3(10): 1-464.

Diaz-Pulido, G. and L. J. McCook. 2002. The fate of bleached corals: patterns and dynamics of algal recruitment. Marine Ecology Progress Series 232: 115-128. DOI: https://doi. org/10.3354/meps232115

Diaz-Pulido, G. and L. J. McCook. 2004. Effects of live coral, epilithic algal communities and substrate type on algal recruitment. Coral Reefs 23: 225-233. DOI: https://doi. org/10.1007/s00338-004-0370-5

Diaz-Pulido, G., A. Chin, J. Davidson and L. J. McCook. 2007. Cyclone promotes rapid colonisation of benthic diatoms in the Great Barrier Reef. Coral Reefs 26: 787. DOI: https://doi. org/10.1007/s00338-007-0269-z

Edmunds, P. J., T. C. Adam, A. C. Baker, S. S. Doo, P. W. Glynn, D. P. Manzello, N. J. Silbiger, T. B. Smith and P. Fong. 2019. Why more comparative approaches are required in time-series analyses of coral reef ecosystems. Marine Ecology Progress Series 608: 297-306. DOI: https://doi.org/10.3354/ meps12805

Gardner, T. A., I. M. Côté, J. A. Gill, A. Grant and A. R. Watkinson. 2005. Hurricanes and Caribbean coral reefs: impacts, 
recovery patterns, and role in long-term decline. Ecology 86(1): 174-184. DOI: https://doi.org/10.1890/04-0141

Guevara-Guillén, C., B. Shirasago-Germán and E. L. Pérez-Lezama. 2015. The influence of large-scale phenomena on La Paz Bay hydrographic variability. Open Journal of Marine Science 5(1): 146-157. DOI: https://doi.org/10.4236/ ojms.2015.51012

Guiry, M. D. and G. M. Guiry. 2020. AlgaeBase-World-wide electronic publication. National University of Ireland. Galway, Ireland. http://www.algaebase.org/ (consulted March, 2020).

Hatcher, B. G. 1984. A maritime accident provides evidence for alternate stable states in benthic communities on coral reefs. Coral Reefs 3(4): 199-204. DOI: https://doi. org/10.1007/BF00288255

Hay, M. E. 1981. The functional morphology of turf-forming seaweeds: persistence in stressful marine habitats. Ecology 62(3): 739-750. DOI: https://doi.org/10.2307/1937742

Hughes, T. P. 1994. Catastrophes, phase shifts, and largescale degradation of a Caribbean coral reef. Science 265(5178): 1547-1551. DOI: https://doi.org/10.1126/ science. 265.5178 .1547

Hurd, C., P. J. Harrison, K. Bischof and C. S. Lobban. 2014. Seaweed Ecology and Physiology. Cambridge University Press. Cambridge, UK. 551 pp.

Iglesias Prieto, R., H. Reyes Bonilla and R. Riosmena-Rodríguez. 2003. Effects of 1997-1998 ENSO on coral reef communities in the Gulf of California, Mexico. Geofísica Internacional 42(3): 467-471.

Lapointe, B. E., P. J. Barile and W. R. Matzie. 2004. Anthropogenic nutrient enrichment of seagrass and coral reef communities in the Lower Florida Keys: discrimination of local versus regional nitrogen sources. Journal of Experimental Marine Biology and Ecology 308(1): 23-58. DOI: https://doi. org/10.1016/j.jembe.2004.01.019

Lirman, D., N. Gracias, B. Gintert, A. C. R. Gleason, G. Deangelo, M. Dick, E. Martinez and R. P. Reid. 2010. Damage and recovery assessment of vessel grounding injuries on coral reef habitats by use of georeferenced landscape video mosaics. Limnology and Oceanography Methods 8(3): 8897. DOI: https://doi.org/10.4319/lom.2010.8.0088

Littler, M. M. and D. S. Littler. 1981. Intertidal macrophyte communities from Pacific Baja California and the upper
Gulf of California: relatively constant vs. environmentally fluctuating systems. Marine Ecology Progress Series 4: 145158.

Littler, M. M. and D. S. Littler. 1984. Models of tropical reef biogenesis: the contribution of algae. Progress in Phycological Research 3: 323-364.

Lüning, K. 1993. Environmental and internal control of seasonal growth in seaweeds. Hydrobiologia 260: 1-14. DOI: https:// doi.org/10.1007/BF00048997

Marshal, P. A. and G. J. Edgar. 2003. The effect of the Jessica grounding on subtidal invertebrate and plant communities at the Galápagos wreck site. Marine Pollution Bulletin 47(7-8): 284-295. DOI: https://doi.org/10.1016/S0025326X(03)00157-7

Mateo-Cid, L. E., I. Sánchez-Rodríguez, Y. E. Rodríguez-Montesinos and M. M. Casas-Valdez. 1993. Estudio florístico de las algas marinas bentónicas de Bahía Concepción, B.C.S., México. Ciencias Marinas 19(1): 41-60. DOI: https://dx.doi. org/10.7773/cm.v19i1.921

Mathieson, A. C. 1989. Phenological patterns of northern New England seaweeds. Botanica Marina 32(5): 419-438. DOI: https://doi.org/10.1515/botm.1989.32.5.419

McCook, L., J. Jompa and G. Diaz-Pulido. 2001. Competition between corals and algae on coral reefs: a review of evidence and mechanisms. Coral Reefs 19: 400-417. DOI: https://doi.org/10.1007/s003380000129

Norris, J. N. 2010. Marine algae of the Northern Gulf of California: Chlorophyta and Phaeophyceae. Smithsonian Contributions to Botany 94: 1-276. DOI: https://doi.org/10.5479/ si.0081024X.94.276

Norris, N. 2014. Marine Algae of the Northern Gulf of California II: Rhodophyta. Smithsonian Contributions to Botany 96: 1-555. DOI: https://doi.org/10.5479/si.19382812.96

Obeso-Nieblas, M. 2003. Variabilidad espacio-temporal de las condiciones oceanográficas de la Bahía de La Paz, B.C.S., México. Tesis de doctorado. Centro Interdisciplinario de Ciencias Marinas-Instituto Politécnico Nacional. La Paz, Baja California Sur, México. 337 pp.

Obeso-Nieblas, M. and A. R. Jiménez-Illescas. 1989. Propagación de la constituyente M2 de la marea en la Bahía de La Paz, B.C.S., México, mediante un modelo bidimensional hidrodinámico numérico. Investigaciones Marinas CICIMAR 4: 242-256. 
Pacheco-Ruíz, I. and J. A. Zertuche-González. 1999. Population structure and reproduction of the carrageenophyte Chondracanthus pectinatus in the Gulf of California. Hydrobiologia 398: 159-166. DOI: https://doi. org/10.1023/A:1017098332403

Paul-Chávez, L. and R. Riosmena-Rodríguez. 2000. Floristic and Biogeographical trends in seaweed assemblages from a subtropical insular island complex in the Gulf of California. Pacific Science 54(2): 137-147.

Petersen, F. T. and R. Meier. 2003. Testing species-richness estimation methods on single-sample collection data using the Danish Diptera. Biodiversity and Conservation 12: 667686. DOI: https://doi.org/10.1023/A:1022495610021

Reyes-Salinas, A., R. Cervantes-Duarte, R. A. Morales-Pérez and J. E. Valdez-Holguín. 2003. Variabilidad estacional de la productividad primaria y su relación con la estratificación vertical en la Bahía de la Paz, B.C.S. Hidrobiológica 13(2): 103-110.

Riosmena-Rodríguez, R. and L. Paul-Chávez. 1997. Sistemática y biogeografía de las macroalgas de la Bahía de La Paz, B.C.S. In: Urbán, J. and M. Ramírez-Rodríguez (eds.). La Bahía de La Paz: Investigación y Conservación. Universidad Autónoma de Baja California Sur (UABCS), Centro Interdisciplinario de Ciencias Marinas-Instituto Politécnico Nacional (CICIMARIPN), SCRIPPS Institution of Oceanography. La Paz, México. Pp. 59-82.

Rocha-Ramírez, V. and D. A. Siqueiros-Beltrones. 1991. El Herbario ficológico de la UABCS: elenco florístico de macroalgas para Balandra en la Bahía de La Paz, B.C.S., México. Revista de Investigación Científica 2(1): 13-34.

Rodríguez-Morales, E. O. and D. A. Siqueiros-Beltrones. 1999. Time variations in a subtropical macroalgal assemblage from the Mexican Pacific. Oceanides 13(2): 11-24.

Rogers, R. W. 1996. Spatial, seasonal and secular patterns in the cover of green algae on Heron reef flat, Great Barrier Reef,
Australia. Botanica Marina 39(1-6): 415-419. DOI: https:// doi.org/10.1515/botm.1996.39.1-6.415

Rogers, R. W. 1997. Brown algae on Heron reef flat, Great Barrier Reef, Australia: spatial, seasonal and secular variation in cover. Botanica Marina 40(1-6): 113-117. DOI: https://doi. org/10.1515/botm.1997.40.1-6.113

Schroeder, R. E., A. L. Green, E. E. DeMartini and J. C. Kenyon. 2008. Long-term effects of a ship-grounding on coral reef fish assemblages at Rose Atoll, American Samoa. Bulletin of Marine Science 82(3): 345-364.

Scrosati, R. 2001. Population dynamics of Caulerpa sertularioides (Chlorophyta: Bryopsidales) from Baja California, Mexico, during El Niño and La Niña years. Journal of the Marine Biological Association of the United Kingdom 81(5): 721726. DOI: https://doi.org/10.1017/S0025315401004520

Setchell, W. A. and N. L. Gardner. 1924. The marine algae: expedition of the California Academy of Sciences to the Gulf of California in 1921. Proceedings of the California Academy of Sciences 12: 695-949.

Tello-Velasco, M. 1986. Cuantificación del efecto de la tormenta tropical "Lidia" y el ciclón "Paul" sobre una comunidad de macroalgas marinas en la laguna costera de Balandra, Baja California Sur, México. Anales del Instituto de Ciencias Marinas y Limnología 13: 69-78.

van Tussenbroek, B. I. and L. Collado-Vides. 2000. Filamentous algae dominate a tropical reef community in the Mexican Caribbean: an unexpected organization of reef vegetation. Botanica Marina 43(6): 547-557 DOI: https://doi. org/10.1515/BOT.2000.055

Woelkerling, W. J. 1990. An introduction. In: Cole, K. M. and R. G. Sheath (eds.). Biology of the red algae. Cambridge University Press. Cambridge, UK. Pp. 1-6.

Zar, J. H. 2009. Biostatistical Analysis. Prentice Hall. Nueva Jersey, USA. 718 pp. 
Appendix: Systematic list of the algae found from 2005 to 2007 in the three studied zones in the San Lorenzo Channel coral reef, La Paz Bay, Gulf of California, Mexico. Presence=1/absence=0 by zone. Growth form (GF): Conspicuous algae (CA), Forming turfs (T).

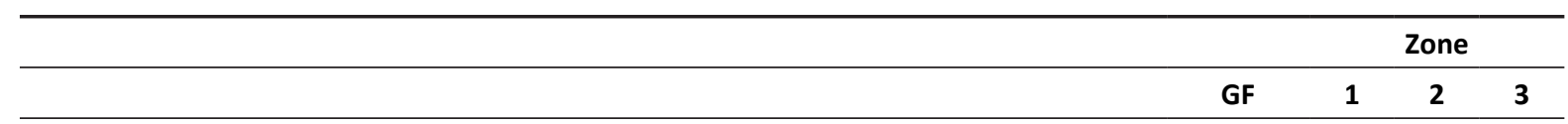

\section{Chlorophyta}

\section{Class Ulvophyceae}

Order Bryopsidales

Bryopsidaceae

Bryopsis pennata J.V. Lamouroux

\section{Caulerpaceae}

Caulerpa chemnitzia (Esper) J.V. Lamouroux

Caulerpa sertularioides (S.G. Gmelin) M.A. Howe

\section{Codiaceae}

Codium amplivesiculatum Setchell \& N.L. Gardner

Codium simulans Setchell \& N.L. Gardner

\section{Derbesiaceae}

Derbesia marina (Lyngbye) Solier

Derbesia sp.

Halimedaceae

Halimeda discoidea Decaisne

Udoteaceae

Chlorodesmis hildebrandtii A. Gepp and E.S. Gepp

Order Cladophorales

\section{Cladophoraceae}

Cladophora albida (Nees) Kützing

Cladophora columbiana Collins

Cladophora microcladioides Collins

Cladophora stimpsonii Harvey

Cladophora sp.

\begin{tabular}{|c|c|c|c|}
\hline $\mathrm{T}$ & 1 & 1 & 1 \\
\hline $\mathrm{T}$ & 1 & 1 & 0 \\
\hline $\mathrm{T}$ & 1 & 1 & 0 \\
\hline CA & 1 & 1 & 1 \\
\hline CA & 1 & 1 & 1 \\
\hline $\mathrm{T}$ & 1 & 0 & 1 \\
\hline $\mathrm{T}$ & 1 & 1 & 0 \\
\hline CA & 1 & 0 & 0 \\
\hline $\mathrm{T}$ & 1 & 0 & 0 \\
\hline $\mathrm{T}$ & 0 & 1 & 1 \\
\hline $\mathrm{T}$ & 1 & 1 & 0 \\
\hline $\mathrm{T}$ & 0 & 0 & 1 \\
\hline $\mathrm{T}$ & 0 & 0 & 1 \\
\hline $\mathrm{T}$ & 1 & 0 & 1 \\
\hline
\end{tabular}

Order Dasycladales

\section{Polyphysaceae}

Parvocaulis parvulus (Solms-Laubach) S. Berger, Fettweiss, Gleissberg, Liddle, U. Richter, Sawitsky \& Zuccarello

Dictyosphaeria versluysii Weber-van Bosse

\section{Order Ulvales}

\section{Ulvaceae}

Ulva clathrata (Roth) C. Agardh

Ulva compressa Linnaeus

Ulva flexuosa Wulfen

Ulva intestinalis Linnaeus

Ulva lactuca Linnaeus

Ulva sp.

Ochrophyta

Class Phaeophyceae

Order Dictyotales

Dictyotaceae

$0 \quad 0 \quad 1$


Appendix: Continuation.

\begin{tabular}{|c|c|c|c|c|}
\hline & \multicolumn{4}{|c|}{ Zone } \\
\hline & GF & 1 & 2 & 3 \\
\hline Dictyota concrescens W.R. Taylor & $\mathrm{T}$ & 1 & 1 & 1 \\
\hline Dictyota crenulata J. Agardh & $\mathrm{CA}$ & 1 & 1 & 1 \\
\hline Dictyota flabellata (F.S. Collins) Setchell \& N.L. Gardner & $\mathrm{CA}$ & 1 & 0 & 1 \\
\hline Lobophora variegata (J.V. Lamouroux) Womersley ex E.C. Olivera & $\mathrm{T}$ & 1 & 1 & 1 \\
\hline Padina concrescens Thivy & $\mathrm{CA}$ & 1 & 1 & 1 \\
\hline Padina durvillei Bory & CA & 1 & 1 & 1 \\
\hline Padina sp. & $\mathrm{T}$ & 0 & 1 & 0 \\
\hline \multicolumn{5}{|l|}{ Order Ectocarpales } \\
\hline \multicolumn{5}{|l|}{ Acinetosporaceae } \\
\hline Feldmannia hemispherica (De A. Saunders) Hollenberg & $\mathrm{T}$ & 1 & 0 & 0 \\
\hline Feldmannia irregularis (Kützing) Hamel & $\mathrm{T}$ & 1 & 0 & 0 \\
\hline Feldmannia rhizoidea Hollenberg \& I.A. Abbott & $\mathrm{T}$ & 0 & 1 & 1 \\
\hline \multicolumn{5}{|l|}{ Ectocarpaceae } \\
\hline Ectocarpus commensalis Setchell \& N.L. Gardner & $\mathrm{T}$ & 1 & 1 & 1 \\
\hline Ectocarpus simulans Setchell \& N.L. Gardner & $\mathrm{T}$ & 0 & 1 & 0 \\
\hline \multicolumn{5}{|l|}{ Scytosiphonaceae } \\
\hline Colpomenia sinuosa (Mertens) Derbès \& Solier & $\mathrm{CA}$ & 1 & 1 & 1 \\
\hline Colpomenia tuberculata De A. Saunders & $\mathrm{CA}$ & 1 & 1 & 1 \\
\hline Hydroclathrus clathratus (C. Agardh) M. Howe & CA & 1 & 1 & 0 \\
\hline Pseudochnoospora implexa J. Agardh & $\mathrm{CA}$ & 1 & 1 & 1 \\
\hline Rosenvingea intricata (J. Agardh) Børgensen & $\mathrm{CA}$ & 1 & 1 & 1 \\
\hline \multicolumn{5}{|l|}{ Order Fucales } \\
\hline \multicolumn{5}{|l|}{ Sargassaceae } \\
\hline Sargassum horridum Setchell \& N.L. Gardner & $\mathrm{CA}$ & 1 & 1 & 1 \\
\hline \multicolumn{5}{|l|}{ Order Sphacelariales } \\
\hline \multicolumn{5}{|l|}{ Lithodermataceae } \\
\hline Pseudolithoderma nigrum Hollenberg & $\mathrm{T}$ & 0 & 1 & 0 \\
\hline \multicolumn{5}{|l|}{ Sphacelariaceae } \\
\hline Sphacelaria brevicornis Setchell \& N.L. Gardner & $\mathrm{T}$ & 0 & 1 & 0 \\
\hline Sphacelaria californica (Sauvageau) Setchell \& N.L. Gardner & $\mathrm{T}$ & 1 & 1 & 1 \\
\hline Sphacelaria rigidula Kützing & $\mathrm{T}$ & 1 & 1 & 1 \\
\hline Sphacelaria tribuloides Meneghini & $\mathrm{T}$ & 1 & 1 & 1 \\
\hline Sphacelaria sp. & $\mathrm{T}$ & 0 & 1 & 1 \\
\hline
\end{tabular}

Rhodophyta

Class Florideophyceae

Order Bonnemaisoniales

Bonnemaisoniaceae

Asparagopsis taxiformis (Delile) Trevisan

CA $\quad 0 \quad 1 \quad 0$

Order Ceramiales

Callithamniaceae

Callithamnion paschale Børgesen

$\begin{array}{llll}\mathrm{T} & 0 & 1 & 1\end{array}$

Ceramiaceae 
Appendix: Continuation.

\begin{tabular}{|c|c|c|c|c|}
\hline & \multicolumn{4}{|c|}{ Zone } \\
\hline & GF & 1 & 2 & 3 \\
\hline Centroceras clavulatum (C. Agardh) Montagne & $\mathrm{T}$ & 0 & 1 & 0 \\
\hline Ceramium camouii E.Y. Dawson & $\mathrm{T}$ & 0 & 1 & 0 \\
\hline Ceramium caudatum Setchell \& N.L. Gardner & $\mathrm{T}$ & 1 & 1 & 1 \\
\hline Ceramium clarionense Setchell \& N.L. Gardner & $\mathrm{T}$ & 0 & 1 & 0 \\
\hline Ceramium equisetoides E.Y. Dawson & $\mathrm{T}$ & 0 & 0 & 1 \\
\hline Ceramium serpens Setchell \& N.L. Gardner & $\mathrm{T}$ & 1 & 1 & 1 \\
\hline Ceramium sinicola Setchell \& N.L. Gardner & $\mathrm{T}$ & 0 & 1 & 0 \\
\hline Ceramium zacae Setchell \& N.L. Gardner & $\mathrm{T}$ & 0 & 0 & 1 \\
\hline Corallophila bella (Setchell \& N.L. Gardner) R.E. Norris & $\mathrm{T}$ & 0 & 0 & 1 \\
\hline Gayliella fimbriata (Setchell \& N.L. Gardner) T.O. Cho and S.M. Boo & $\mathrm{T}$ & 1 & 1 & 0 \\
\hline Gayliella flaccida (Harvey) T.O. Cho \& L.J. Mclvor & $\mathrm{T}$ & 1 & 1 & 1 \\
\hline Gayliella taylorii (E.Y. Dawson) T.O. Cho \& S.M. Boo & $\mathrm{T}$ & 1 & 1 & 1 \\
\hline \multicolumn{5}{|l|}{ Delesseriaceae } \\
\hline Dasya sinicola (Setchell \& N.L. Gardner) E.Y. Dawson & $\mathrm{T}$ & 1 & 1 & 1 \\
\hline Heterosiphonia crispella var. laxa (Børgensen) M.J. Wynne & $\mathrm{T}$ & 1 & 0 & 1 \\
\hline Heterosiphonia erecta N.L. Gardner & $\mathrm{T}$ & 0 & 0 & 1 \\
\hline \multicolumn{5}{|l|}{ Rhodomelaceae } \\
\hline Chondria acrorhizophora Setchell \& N.L. Gardner & $\mathrm{T}$ & 1 & 1 & 1 \\
\hline Chondria arcuata Hollenberg & $\mathrm{T}$ & 1 & 1 & 1 \\
\hline Chondria dasyphylla (Woodward) C. Agardh & CA & 1 & 1 & 0 \\
\hline Digenea simplex (Wulfen) C. Agardh & $\mathrm{CA}$ & 1 & 1 & 1 \\
\hline Herposiphonia littoralis Hollenberg & $\mathrm{T}$ & 1 & 1 & 1 \\
\hline Herposiphonia spinosa E.Y. Dawson & $\mathrm{T}$ & 0 & 1 & 0 \\
\hline Laurencia hancockii E.Y. Dawson & $\mathrm{T}$ & 1 & 1 & 1 \\
\hline Laurencia pacifica Kylin & $\mathrm{CA}$ & 1 & 1 & 1 \\
\hline Laurencia sp. & $\mathrm{T}$ & 1 & 1 & 1 \\
\hline Melanothamnus hancockii (E.Y. Dawson) Díaz-Tapia \& Maggs & $\mathrm{T}$ & 1 & 0 & 0 \\
\hline Melanothamnus johnstonii (Setchell \& N.L. Gardner) Díaz-Tapia \& Maggs & $\mathrm{T}$ & 1 & 0 & 1 \\
\hline Melanothamnus masonii (Setchell \& N.L. Gardner) Díaz-Tapia \& Maggs & $\mathrm{T}$ & 1 & 1 & 1 \\
\hline Melanothamnus simplex (Hollenberg) Díaz-Tapia \& Maggs & $\mathrm{T}$ & 1 & 1 & 1 \\
\hline Osmundea sinicola (Setchell \& N.L. Gardner) K.W. Nam & $\mathrm{T}$ & 1 & 0 & 1 \\
\hline Palisada pedrochei J.N. Norris & $\mathrm{CA}$ & 1 & 0 & 0 \\
\hline Polysiphonia mollis J.D. Hooker \& Harvey & $\mathrm{T}$ & 1 & 1 & 1 \\
\hline Polysiphonia pacifica Hollenberg & $\mathrm{T}$ & 1 & 1 & 1 \\
\hline Polysiphonia sertularioides (Grateloup) J. Agardh & $\mathrm{T}$ & 1 & 1 & 1 \\
\hline Polysiphonia scopulorum var. villum (J. Agardh) Hollenberg & $\mathrm{T}$ & 0 & 1 & 1 \\
\hline Vertebrata hendryi (N.L. Gardner) A.M. Savoie \& G.W. Saunders & $\mathrm{T}$ & 1 & 0 & 0 \\
\hline \multicolumn{5}{|l|}{ Wrangeliaceae } \\
\hline Anotrichium furcellatum (J. Agardh) Baldock & $\mathrm{T}$ & 1 & 1 & 1 \\
\hline Anotrichium tenue (C. Agardh) Nägeli & $\mathrm{T}$ & 1 & 1 & 1 \\
\hline Tiffaniella phycophila (W.R. Taylor) E.M. Gordon & $\mathrm{T}$ & 0 & 1 & 0 \\
\hline Tiffaniella saccorhiza (Setchell \& N.L. Gardner) Doty \& Meñez & $\mathrm{T}$ & 0 & 0 & 1 \\
\hline Pleonosporium squarrulosum (Harvey) I.A. Abbot & $\mathrm{T}$ & 0 & 1 & 0 \\
\hline
\end{tabular}


Appendix: Continuation.

\section{Order Corallinales}

\section{Corallinaceae}

Jania adhaerens J.V. Lamouroux

Jania tenella (Kützing) Grunow

\section{Lithophyllaceae}

Amphiroa beauvoisii J.V. Lamouroux

Amphiroa valonioides Yendo

Order Gelidiales

Gelidiaceae

Gelidium johnstonii Setchell \& N.L. Gardner

Gelidium pusillum (Stackhouse) Le Jolis

Gelidium refugiense (E.Y. Dawson) Santelices

\section{Gelidiellaceae}

Gelidiella hancockii E.Y. Dawson

\section{Pterocladiaceae}

Pterocladiella caloglossoides (M.A. Howe) Santelices

$\begin{array}{llll}\mathrm{T} & 1 & 1 & 1 \\ \mathrm{~T} & 1 & 1 & 1 \\ & & & \\ \mathrm{~T} & 0 & 1 & 1 \\ \mathrm{~T} & 1 & 1 & 0\end{array}$

Order Gigartinales

Cystocloniaceae

Hypnea pannosa J. Agardh

Hypnea spinella (C. Agardh) Kützing

Hypnea valentiae (Turner) Montagne

Hypnea sp.

$\begin{array}{cccc}\mathrm{CA} & 0 & 0 & 1 \\ \mathrm{~T} & 0 & 1 & 1 \\ \mathrm{~T} & 0 & 0 & 1 \\ & & & \\ \mathrm{~T} & 1 & 1 & 1 \\ & & & \\ \mathrm{~T} & 1 & 0 & 0\end{array}$

\section{Solieriaceae}

Wurdemannia miniata (Sprengel) Feldmann \& Hamel

$\begin{array}{clll}\text { CA } & 1 & 1 & 1 \\ \mathrm{CA} & 1 & 1 & 1 \\ \mathrm{CA} & 1 & 0 & 0 \\ \mathrm{~T} & 1 & 1 & 0 \\ & & & \\ \mathrm{~T} & 0 & 1 & 1\end{array}$

Order Gracilariales

Gracilariaceae

Gracilaria crispata Setchell \& N.L. Gardner

Gracilaria marcialana E.Y. Dawson

$\begin{array}{llll}\text { CA } & 1 & 1 & 1 \\ \text { CA } & 1 & 0 & 0 \\ \text { CA } & 1 & 0 & 0 \\ \text { CA } & 0 & 0 & 1\end{array}$

Gracilaria textorii (Suringar) De Hariot

Order Halymeniales

\section{Halymeniaceae}

Prionitis abbreviata Setchell \& N.L. Gardner

Prionitis delicatula (W.R. Taylor) E.Y. Dawson

$\begin{array}{llll}\mathrm{CA} & 0 & 1 & 0 \\ \mathrm{CA} & 0 & 1 & 0\end{array}$

Order Nemaliales

Scinaiaceae

Scinaia johnstoniae Setchell

Order Peysonneliales

Peyssonneliaceae

Peyssonnelia orientalis (Weber-van Bosse) Cormaci \& G.Furnari

$\begin{array}{llll}\mathrm{T} & 0 & 1 & 0\end{array}$

Order Rhodymeniales

Champiaceae 
Appendix: Continuation.

\begin{tabular}{|c|c|c|c|c|}
\hline & \multicolumn{4}{|c|}{ Zone } \\
\hline & GF & 1 & 2 & 3 \\
\hline \multicolumn{5}{|l|}{ Lomentariaceae } \\
\hline Ceratodictyon variabile (J. Agardh) R.E. Norris & CA & 0 & 1 & 0 \\
\hline Lomentaria hakodatensis Yendo & $\mathrm{T}$ & 1 & 1 & 1 \\
\hline \multicolumn{5}{|l|}{ Rhodymeniaceae } \\
\hline Irvinea hancockii (E.Y. Dawson) R.J. Wilkes, L.M. Mclvor \& Guiry & CA & 1 & 1 & 1 \\
\hline Rhodymenia hancockii E.Y. Dawson & CA & 0 & 1 & 0 \\
\hline
\end{tabular}

